\title{
Teawaste as An Adsorbent for Heavy Metal Removal from Industrial Wastewaters
}

\author{
${ }^{1}$ Amir Hossein Mahvi, ${ }^{2}$ Dariush Naghipour, ${ }^{2}$ Forugh Vaezi and ${ }^{2}$ Shahrokh Nazmara \\ ${ }^{1}$ Center for Environmental Research , \\ ${ }^{2}$ Department of Environmental Health Engineering, Tehran University of Medical Sciences \\ Tehran, Iran
}

\begin{abstract}
Water used in industries creates a wastewater that has a potential hazard for our environment because of introducing various contaminants such as heavy metals into soil and water resources. In this study, removal of cadmium, lead and nickel from industrial wastewaters has been investigated by using teawaste as a natural adsorbent. The research is a bench scale experimental type and analyses have performed by using different amounts of adsorbent in solutions with 5 different concentrations of each metal and also in a mixed combination. Besides, the effect of various amounts of teawaste used in adsorption efficiency experiments has been investigated. Results indicate that the removal efficiency is highest for lead and is minimum for cadmium. About 94 and $100 \%$ lead removal were achieved by using 0.5 and $1.5 \mathrm{~g}$ adsorbent for solutions having concentrations of 5 and $10 \mathrm{mg} / \mathrm{L}$ $\mathrm{Pb}$. Whereas, $1.5 \mathrm{~g}$ teawaste can treat nickel solution of $5 \mathrm{mg} / \mathrm{L}$ concentration with an efficiency of not more that $85.7 \%$. For cadmium, the efficiency was only $77.2 \%$ in the same conditions. On the other hand, for mixtures of metals and by applying $0.5 \mathrm{~g}$ teawaste, we considered a $3.5 \%$ decrease in lead removal efficiency and a $13.2 \%$ decrease in nickel adsorption for a mixed solution of $5 \mathrm{mg} / \mathrm{L}$.
\end{abstract}

Key words: Teawaste , Heavy Metals, Adsorption, Industrial Wastewaters

\section{INTRODUCTION}

Toxic metals are often discharged by a number of industrial processes and this can lead in turn to the contamination of freshwater and marine environment [1]. Heavy metals are major pollutants in marine, ground, industrial and even treated wastewaters. [2]. Industrial waste constitutes the major source of various kinds of metal pollution in natural waters. The important toxic metals i.e. $\mathrm{Cd}, \mathrm{Zn}, \mathrm{Ni}$, and $\mathrm{Pb}$ finds its way to the water bodies through waste waters [3]. The release of large quantities of HMs into the natural environment e.g. irrigation of agricultural fields by using sewage has resulted in a number of environmental problems [4-6] and due to their non-biodegradability and persistence, can accumulate in the environment elements such as food chain, and thus may pose a significant danger to human health $[7,8]$.

Many physico-chemical methods have been proposed for their removal from industrial effluents [9]. Adsorption is an effective purification and separation technique used in industry especially in water and wastewater treatments. [10].

Cost is an important parameter for comparing the sorbent materials [11]. Byproducts of soybean and cottonseed hulls, rice straw and sugarcane bagasse were evaluated as metal ion adsorbents in aqueous solutions $[12,13]$.
In this study, the efficiency of teawaste has been determined in the process of heavy metal removing from both single metal solutions and various mixtures. Metals of interest were cadmium and lead. They were chosen based on their industrial applications and potential pollution impact on the environment. Cadmium is a non-essential and non-beneficial element to plants and animals. Lead is a hazardous waste and is highly toxic to humans, plants and animals [1] and $\mathrm{Ni}$ is one of important toxic metals [14].

\section{MATERIALS AND METHODS}

In this study, teawaste has been used for adsorption experiments. This teawaste bas been washed at the first step and then rinsed with distilled water. After drying in $100^{\circ} \mathrm{C}$, it was ground and screened (using screen with mesh size 10). For preservation, it was kept in plasticstopper bottle (containers) and to minimize contact with humidity all these bottles were preserved in a desiccators before the time of use.

Individual and mixed solutions of $\mathrm{Ni}, \mathrm{Pb}$ and $\mathrm{Cd}$ with 5 different concentrations of 5, 10, 15, 30 and $100 \mathrm{mg} / \mathrm{L}$ where prepared synthetically and in order to determine the efficiency of teawaste in metal adsorption, the experiments were performed using 3 different amounts of adsorbent: $0.5,1$ and $1.5 \mathrm{~g}$ in single solution. The procedure for first experiment was as follows: to 15 
flasks each containing $0.5 \mathrm{~g}$ adsorbent, $100 \mathrm{ml}$ of solutions with known concentration of lead were added, thereupon we had 3 similar concentrations for each experiment, for example, 5 flasks containing $0.5 \mathrm{mg} / \mathrm{L}$ and the other 3 containing $10 \mathrm{mg} / \mathrm{L}$ lead and so forth. All these flasks were then located on a shaker with 120 - $130 \mathrm{rpm}$. After one hour contact time, the contents of flasks were filtered through Whitman No.40 filter paper to prevent the probable interference of turbidity. The lead concentration of filtered solutions was then determined using atomic adsorption spectrophotometery. The same procedure was repeated for $\mathrm{Cd}$ and $\mathrm{Ni}$. However, and as it would be indicated in the Tables, results of experiments with individual solutions were somehow different from mixed solutions of these metals.

\section{RESULTS AND DISCUSSION}

Results of this study indicate that the adsorption efficiency is maximum for $\mathrm{Pb}$ and minimum for $\mathrm{Cd}$ (Tables 1 to 3 ). Table 1 shows the residual concentration of lead in solution after 1 hour contact time and Fig. 1 represents the adsorption efficiency for various concentrations of lead. As it is obvious teawaste is a wonderful adsorbent for removal of lead from wastewater. The adsorption rate is dependant on adsorbent amount and initial concentration of metal in synthetic solutions. Increases in adsorption by increasing the amount of adsorbent seem to be an effect of increase in adsorption sites. Thereby it is passable to have increased adsorption by grinding the adsorbent. For example, $94 \%$ removal of lead from a $5 \mathrm{mg} / \mathrm{L}$ solution was possible by applying $0.5 \mathrm{~g}$ teawaste whereas the similar amount of adsorbent was not enough to treat a $100 \mathrm{mg} / \mathrm{L}$ lead solution to more than about $76 \%$. But by increasing the amount of teawaste to $1.5 \mathrm{~g}$ it was possible to increase the efficiency of adsorption to about $96.5 \%$ for the same solution (100 $\mathrm{mg} / \mathrm{L} \mathrm{Pb}$ ). So we would have better treatment by using excess teawaste. As this adsorbent is cheap and available there would be no problem to increase its consumption [14].

By comparing the results of the study presented in Tables 2 and 4 we also conclude that the adsorption efficiency is dependent to the type of metal too, as for $\mathrm{Ni}$ we haven't more than $76 \%$ removal in the same conditions $(0.5 \mathrm{~g}$ adsorbent in solutions of 5, 10, 15, 30 and $100 \mathrm{mg} / \mathrm{L}$ ), but for $\mathrm{Pb}$ and $\mathrm{Cd}$ the efficiencies are reported to be 94 and $60 \%$ respectively (Tables and Figs. 1- 3).

Tables (4-5) represent the results of adsorption experiments conducted on the mixtures of metals solutions. As mentioned before, the maximum and minimum removal efficiencies in the

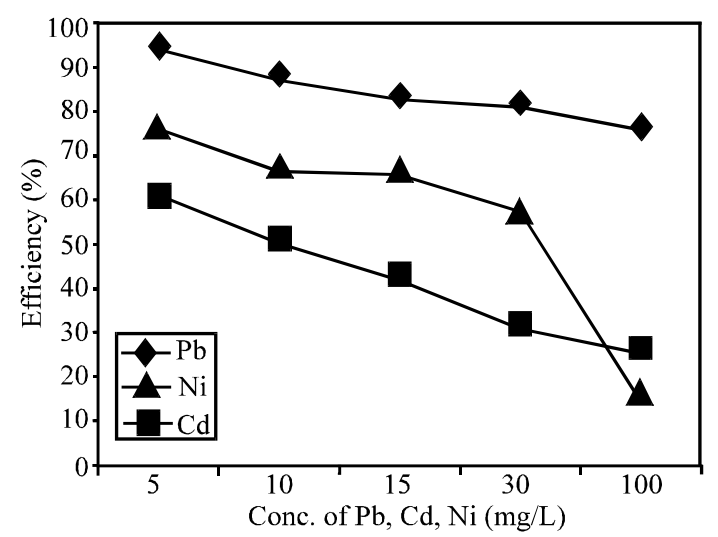

Fig. 1: Adsorption Percent of Lead, Cadmium and Nickel by $0.5 \mathrm{~g}$ Teawaste

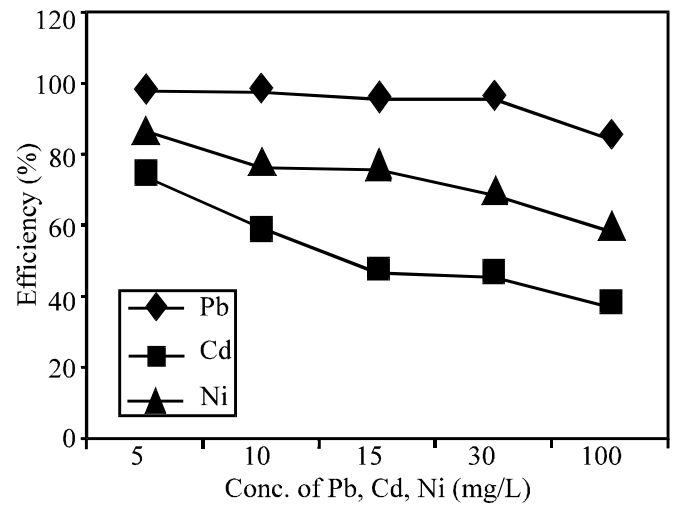

Fig. 2: Adsorption Percent of Lead, Cadmium and Nickel by $1.0 \mathrm{~g}$ Teawaste

first stage of experiments with $0.5 \mathrm{~g}$ adsorbent were 94 and $76.3 \%$ for Lead and 76 and $14.8 \%$ for Ni, 60 and $24.8 \%$ for $\mathrm{Cd}$. But for the mixture of these metals, a $3.5 \%$ decrease has been observed for lead adsorption whereas $\mathrm{Ni}$ adsorption has decreased in most concentrations $(12.2 \%)$.

Table 1:Concentration of Residual Lead After Adsorption by Teawaste

$\mathrm{Pb} \mathrm{mg} / \mathrm{L}$

$\mathrm{C}_{0}$

Quantity

of tea waste $(\mathrm{g})$

\begin{tabular}{llllll}
$\mathrm{m}$ & 5 & 10 & 15 & 30 & 100 \\
\hline 0.5 & 0.3 & 1.2 & 2.5 & 5.5 & 23.9 \\
& 0.31 & 1.1 & 2.6 & 5.35 & 23.8 \\
& 0.3 & 1.3 & 2.5 & 5.7 & 23.6 \\
1 & 0.09 & 0.2 & 0.6 & 1 & 3.5 \\
& 0.08 & 0.2 & 0.5 & 1.2 & 3.8 \\
& 0.09 & 0.15 & 0.5 & 1.1 & 3.9 \\
1.5 & 0 & 0 & 0.4 & 0.7 & 3.8 \\
& 0 & 0 & 0.3 & 0.8 & 3.5 \\
& 0 & 0 & 0.5 & 0.9 & 3.4 \\
\hline
\end{tabular}




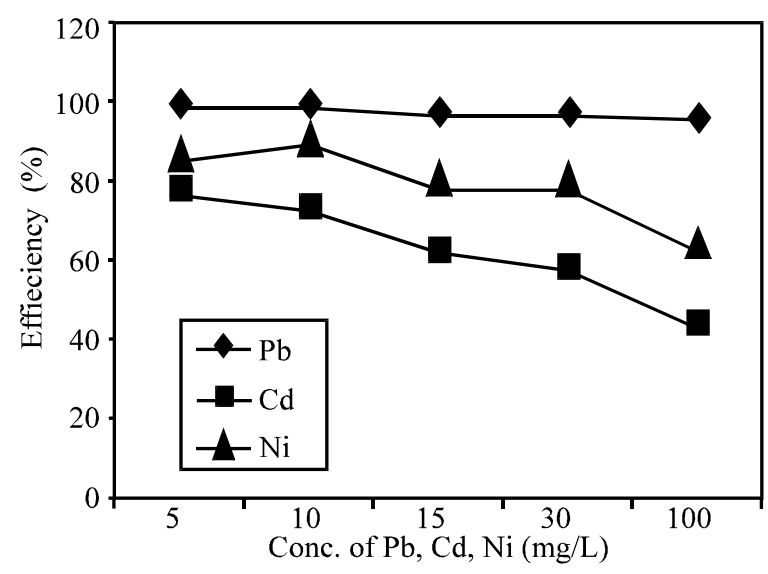

Fig. 3: Adsorption Percent of Lead, Cadmium and Nickel by $1.5 \mathrm{~g}$ Teawaste

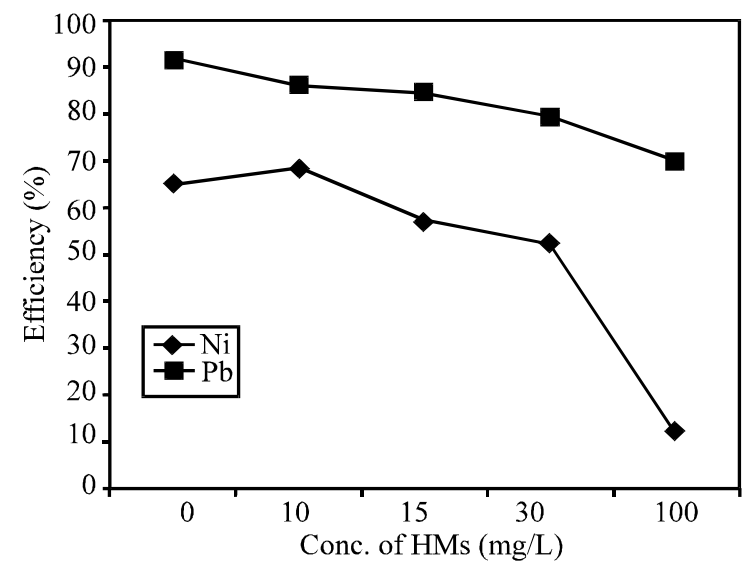

Fig. 4: Adsorption Percent of Lead and Nickel in Mixed Metals Solution by Using $0.5 \mathrm{~g}$ Teawaste

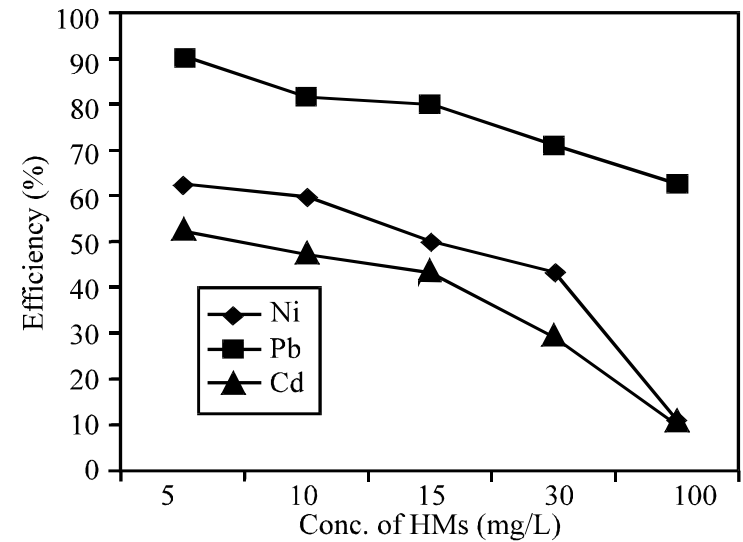

Fig. 5: Adsorption Percent of Lead, Nickel and Cadmium in Mixed Metals Solution by Using $0.5 \mathrm{~g}$ Teawaste

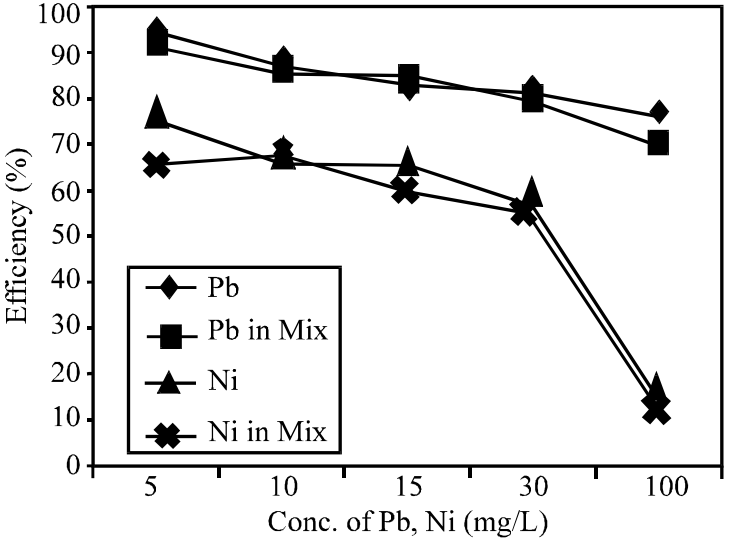

Fig. 6: A Comparison Between Adsorption Percent of Lead and Nickel in Individual and Mixed Metals Solutions by $0.5 \mathrm{~g}$ Teawaste

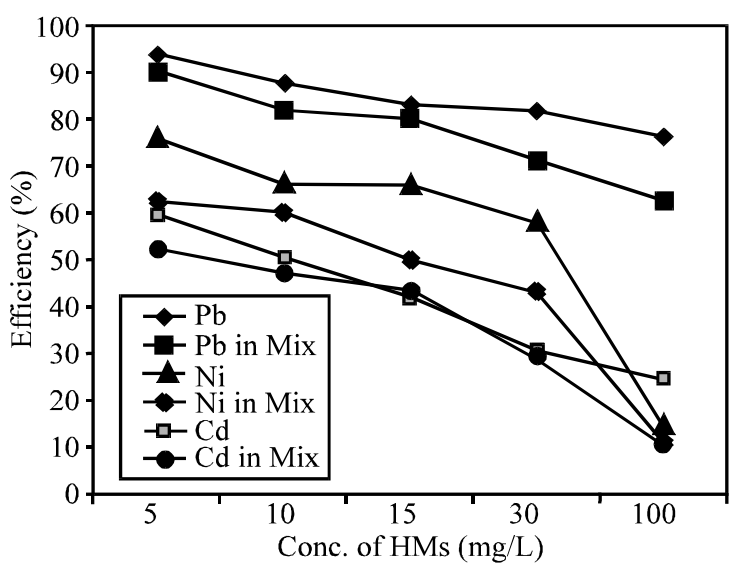

Fig. 7: A Comparison between Adsorption Percent of Lead, Nickel and Cadmium in Individual and Mixed Metals Solutions by $0.5 \mathrm{~g}$ Teawaste

Table 2: Concentration of Residual Nickel after Adsorption by Teawaste

\begin{tabular}{|c|c|c|c|c|c|}
\hline $\begin{array}{l}\text { Ni n } \\
\mathrm{C}_{0} \\
\text { Qua } \\
\text { of te }\end{array}$ & $\begin{array}{l}\text { ty } \\
\text { vaste }\end{array}$ & & & & \\
\hline $\mathrm{m}$ & 5 & 10 & 15 & 30 & 100 \\
\hline 0.5 & 1.2 & 3.63 & 5.27 & 13.11 & 83.25 \\
\hline & 1.25 & 3.49 & 5.18 & 12.9 & 85.23 \\
\hline & 1.17 & 3.1 & 4.83 & 11.87 & 87.23 \\
\hline 1 & 0.7 & 2.29 & 3.76 & 8.3 & 42.8 \\
\hline & 0.65 & 2.35 & 3.52 & 10.78 & 42.51 \\
\hline & 0.65 & 2.2 & 3.62 & 9.2 & 42.35 \\
\hline 1.5 & 0.7 & 1.58 & 3.1 & 6.24 & 37.68 \\
\hline & 0.6 & 1.6 & 3.3 & 6.15 & 37.52 \\
\hline & 0.85 & 1.55 & 3.8 & 6.3 & 37.91 \\
\hline
\end{tabular}


Table 3: Concentration of Residual Cadmium After Adsorption by Teawaste

\begin{tabular}{|c|c|c|c|c|c|}
\hline $\begin{array}{l}\mathrm{Cd} \\
\mathrm{C}_{0} \\
\text { Qua } \\
\text { of t }\end{array}$ & aste (g & & & & \\
\hline $\mathrm{m}$ & 5 & 10 & 15 & 30 & 100 \\
\hline$\overline{0.5}$ & 2.10 & 5.1 & 8.7 & 21.1 & 75.0 \\
\hline & 1.90 & 4.8 & 8.8 & 20.2 & 76.0 \\
\hline & 2.00 & 4.9 & 8.7 & 20.8 & 74.7 \\
\hline 1 & 1.31 & 4.1 & 8.1 & 16.1 & 63.0 \\
\hline & 1.25 & 3.9 & 7.9 & 16.2 & 61.0 \\
\hline & 1.37 & 4.0 & 8.2 & 16.0 & 62.5 \\
\hline 1.5 & 0.90 & 2.8 & 6.0 & 12.3 & 56.3 \\
\hline & 0.92 & 2.6 & 5.5 & 12.9 & 57.8 \\
\hline & 1.00 & 2.7 & 5.6 & 12.8 & 56.9 \\
\hline
\end{tabular}

Table 4:Concentration of Residual Metals in Mixed Metal Solution Using $0.5 \mathrm{~g}$ Teawaste

\begin{tabular}{llllll}
\hline \multicolumn{2}{l}{$\mathrm{C}_{0} \mathrm{mg} / \mathrm{L}$} \\
$\mathrm{m} \mathrm{mg} / \mathrm{L}$ & & 10 & 15 & 30 & 100 \\
\hline $\mathrm{Ni}$ & 1.87 & 3.2 & 6.8 & 14.54 & 87.4 \\
& 1.95 & 3.17 & 6.36 & 14.12 & 88.0 \\
& 1.57 & 3.1 & 6.52 & 14.25 & 87.7 \\
$\mathrm{~Pb}$ & 8.2 & 13.9 & 14.7 & 20.5 & 29.7 \\
& 8.5 & 13.5 & 14.8 & 20.4 & 29.6 \\
& 7.9 & 13.7 & 15.2 & 20.3 & 30.4 \\
\hline
\end{tabular}

Table 5:Mean Concentration of Residual Metals in Mixed Metals Solution After Adsorption by 0.5 g Teawaste

\begin{tabular}{llllll}
\hline \multicolumn{2}{l}{$\mathrm{C}_{0} \mathrm{mg} / \mathrm{L}$} & & & & \\
$\mathrm{m} \mathrm{mg} / \mathrm{L}$ & & 10 & 15 & 30 & 100 \\
\hline $\mathrm{Ni}$ & 1.86 & 3.99 & 7.47 & 16.95 & 88.9 \\
$\mathrm{~Pb}$ & 0.475 & 1.79 & 2.95 & 8.58 & 37.3 \\
$\mathrm{Cd}$ & 2.38 & 5.27 & 8.47 & 21.18 & 89.3 \\
\hline
\end{tabular}

The efficiencies of $\mathrm{Pb}, \mathrm{Cd}$ and $\mathrm{Ni}$ adsorption by various amounts of teawastes can be seen in Figs. 1 to 3 for individual solutions and for mixed solution of $\mathrm{Pb}$ and $\mathrm{Ni}$ and $\mathrm{Cd}$ (Figs. 4 and 5) and in comparison to individual solutions in Figs. 6 and 7.

\section{CONCLUSION}

Analyses of results of this study have indicated that teawaste like the most other natural absorbents can be used in the treatment process of heavy metals and the treatment efficiency may be as high as $100 \%$ by precise choosing of adsorbent amount. The concentration of heavy metal has also an important effect on the result of this treatment. Teawaste is a cheep material so its utilizing in industrial wastewater treatment plants would be convenient. Meanwhile it is possible to increase the treatment efficiency by pretreatment with some chemicals such as acids, bases and detergents [14]. Finally we recommend to evaluate the effect of pretreatment processes for this type of treatment and to investigate the probable changes of adsorption efficiency in conditions of encountering the various metals in actual wastewaters.

\section{REFERENCES}

1. Low, K.S., C.K. Lee and S.C. Liew, 2000. Sorption of cadmium and lead from aqueous solution by spent grain. Process Biochemistry, 36: 59-64.

2. Valdman, E., L. Erijman, F.L.P. Pessoa, S.G.F. Leite, 2001. Continuous biosorption of $\mathrm{Cu}$ and $\mathrm{Zn}$ by immobilized waste biomass Sargassum sp. Process Biochemistry, 36: 869-873.

3. Ajmal, M., A. Mohammad, R. Yousuf and A. Ahmad, 1998. Adsorption behavior of Cadmium, Zink, Nickel, and Lead from aqueous solution by Mangifera India Seed Shell. India J. Environ Hlth. 40: 15-26.

4. Kaewsarn, P. and Q. Yu, 2001. Cadmium(II) removal from aqueous solutions by pre-treated biomass of marine alga Padina sp. Environmental Pollution, 112: 209-213

5. Yan, G. and T. Viraraghavan, 2001. Heavy metal removal in a biosorption column by immobilized M. rouxii biomass. Bioresource Technology, 78: 243- 249

6. Bansal, O.P., 1996. Heavy metal pollution of soils and plants to sewage irrigation. India J. Environ Hlth., 40: 51-57.

7. Bakkaloglu, I., T.J. Butter, L.M. Evison, F.S. Holland and I.C. Hancock, 1998. Screening of various types biomass for removal and recovery of heavy metals $\mathrm{Zn}$, $\mathrm{Cu}, \mathrm{Ni}$ ) by biosorption, sedimentation and desorption. Wat. Sci. Tech., 38: 269-277

8. Yetis, U., G. Ozcengiz, B. Filiz, N. Ergen, A. Erbay and A. Dolek, 1998. Heavy Metal biosorption by White-Rot Fungi. Wat. Sci. Tech., 38: 323-330.

9. Iqbal, M., A. Saeed, and N. Akhtar, 2002. Petiolar feltsheath of palm: a new biosorbent for the removal of heavy metals from contaminated water. Bioresource Technology, 81: 151-153.

10. Al-Asheh, S., F. Banat, R. Al-Omari, and Z. Duvnjak, 2000. Predictions of binary sorption isotherms for the sorption of heavy metals by pine bark using single isotherm data. Chemosphere, 41: 659-665

11. Bailey, S. E, T.L. Olin, R.M. Bricka, and D.D. Adrian, 1999. A review of potentially low-cost sorbents for heavy metals. Wat. Res., 33: 2469-2479.

12. Marshall, W.E. and E.T. Champagne, 1995. Agricultural byproducts as adsorbents for metal ions in laboratory prepared solutions and in manufacturing waste water. J. Environ. Sci. Hlth, 2: 241-261.

13. Marshall, W.E., E.T. Champagne, and W.J. Evans, 1993. Use of rice milling byproducts (Hulls \& Bran) to remove metal ions as aqueous solution. J. Environ. Sci. Health, $9: 1977-1992$.

14. Ajmal, M., A. Hussain Khan, S. Ahmad and A. Ahmad, 1998. Role of sawdust in the removal of copper(II) From industrial wastes. Wat. Res. 32: 3085-3091. 